\title{
Should Jatiluhur Reservoir Apply the Zero Floating Fish Cage?
}

\author{
Grace Sondang Yunika ${ }^{1}$, Mahawan Karuniasa ${ }^{2}$ \\ \{grace.sondang81@ui.ac.id ${ }^{1}$ \} \\ Universitas Indonesia, Indonesia ${ }^{1,2}$
}

\begin{abstract}
River basin is a unitary area with rivers and tributaries, which serves to hold, store, and drain the water coming from precipitation to the lake or to the sea naturally, the boundary on land is a separator topographic and boundary at sea up to the area of water still affected land activity. Prevention of pollution of river basin in the form of integrated and thorough planning activities in the prevention pattern of pollution and/or the destruction of watershed through physical and/or non-physical activities or through the balancing of upstream and downstream Citarum river basin. Jatiluhur Reservoir is included into the Citarum river basin which has a versatile function especially for the development of floating fish cage farming (KJA). In 2015 the population of floating nets has reached 25,951 plots. The activity of floating nets is indicated to potentially pollute the quality of reservoir water. Jatiluhur reservoir pollution will affect the quality of Citarum basin. Based on the indications of the government to issue presidential regulation Number 15 year 2018 about accelerating pollution control and destruction of Citarum river basin. Through this regulation, zero KJA policy was issued at Jatiluhur Reservoir. The purpose of this article is to review whether zero KJA policy needs to be applied in the Jatiluhur reservoir. The methods used in this study are geography information systems (GIS) and literature study. The results of this study in the form of zero KJA need to be applied in Jatiluhur Reservoir. However, KJA fish cultivation need to look for other alternative such as culture-based fisheries (CBF). CBF fish cultivation is considered more environmentally friendly than KJA. The cultivation of fish in Jatiluhur Reservoir is not discharged because Jatiluhur Reservoir is one of the producers and suppliers of freshwater fish in West Java.
\end{abstract}

Keywords: Floating Fish Cage, Citarum River Basin Contamination, Jatiluhur Reservoir, Zero KJA.

\section{Introduction}

River basin is a unitary area with rivers and tributaries, which serves to hold, store, and drain the water coming from precipitation to the lake or to the sea naturally, the boundary on land is a separator Topographic and boundary at sea up to the area of waters still affected by land activities [1]. Citarum river basin is traversed by the Citarum River which has a length of $269 \mathrm{~km}$ with spring in Bandung Regency and flows through 12 districts in West Java and is inhabited by more than 18 million inhabitants [2].

Citarum River is divided into 3 area zones, namely the upper Citarum Zone with the river upstream at the Mount Wayang and the river end in Saguling; Central Citarum Zone with the upstream river at Saguling and end of the river in Jatiluhur and downstream Citarum Zone 
with upstream river in Jatiluhur and the riverbank at the Citarum river basin [3]. The problems in the upper Citarum area were caused by reduced function of both forest and non-forest protected areas, the growing settlements without good planning, and agricultural cultivation that did not comply with the conservation rules that caused the number of critical land, the higher erosion rate that resulted in the sedimentation in the trough of rivers, reservoirs, even into the water infrastructure network [3]. In addition, other problems are rivers polluted settlements, industry and agriculture due to the behavior of people who make the river as a place of wastewater because of the management of waste has not been properly managed so Citarum River is dominant for flooding, waste and domestic waste industry and waste [3].

The Citarum problem is so complex, so that the government issued a rule of Presidential Regulation Number 15 year 2018 about Accelerating Pollution Control and Destruction of Citarum River Basin. This regulation aims to form a team to accelerate the pollution control and a breakdown of Citarum river basin. The team performs the implementation of pollution prevention operations and the Citarum river basin by conducting socialization and education by providing information on the pollution and destruction of Citarum river basin to the community, handling waste and recovery of ecosystems, coordinate the relocation of affected communities in the Citarum river basin, coordinate in the update of data and information needed in response to pollution and damage of Citarum river basin with Related institutions, innovating in the prevention and destruction of Citarum river basin in accordance with the development of science and technology, community empowerment and prevention and enforcement of the law [1].

Jatiluhur Reservoir is part of the Citarum river basin. The reservoir is entered into the central Citarum Zone. This reservoir has a variety of functions, namely generating electricity, drain irrigation for 234,000 ha rice fields, as a raw material of drinking water, as a place for the cultivation of floating nets (KJA) as well as for tourism function [4][5]. KJA cultivation was first tried in 1974 in Jatiluhur Reservoir under the management of Jasa Tirta II and began to be cultivated in 1988 [6]. KJA intensive cultivation pattern makes KJA farmers provide as many feed so that fish can grow and immediately harvested. The uneaten fish feed then settlers and pollutes the quality of the reservoir water. Water quality pollution due to fish feed not only affects the reservoir, but also affects Citarum river. Given the raw water to drink is provided by Jatiluhur Reservoir and flows downstream through Citarum River. Stakeholders decided to control the pollution and damage of Citarum river basin by issuing a KJA zero policy in Jatiluhur Reservoir. The purpose of this article is to review whether the KJA zero policy needs to be applied in the reservoir Jatiluhur.

\section{Research Methods}

The methods used in this research are geographic information systems (GIS) as well as literature studies from the past 19 years which is 2000-2018. The data can be quantitatively described through literature study. This descriptive approach describes existing data and was presented into narrative form. Data of the field carried out in the year 2016 also added. Field data was processed with a spatial approach (spline) resulting in a distribution of phosphorus and nitrogen values. In this research the author wants to compare the reservoir water quality condition year after year. 


\section{Result and Discussion}

\subsection{Overview of Jatiluhur Reservoir}

Jatiluhur Reservoir is located in Jatiluhur Sub-district, Purwakarta Regency, West Java Province. Jatiluhur Reservoir is the largest artificial reservoir in Indonesia. The reservoir is located at an altitude of $111 \mathrm{~m}$ above sea level with an area of 7,780 hectares and an average depth of $32.9 \mathrm{~m}$ [7]. As mentioned earlier, Jatiluhur Reservoir is a place for KJA cultivation. KJA research in Jatiluhur Reservoir has been started since 2000 by Sutardjo.

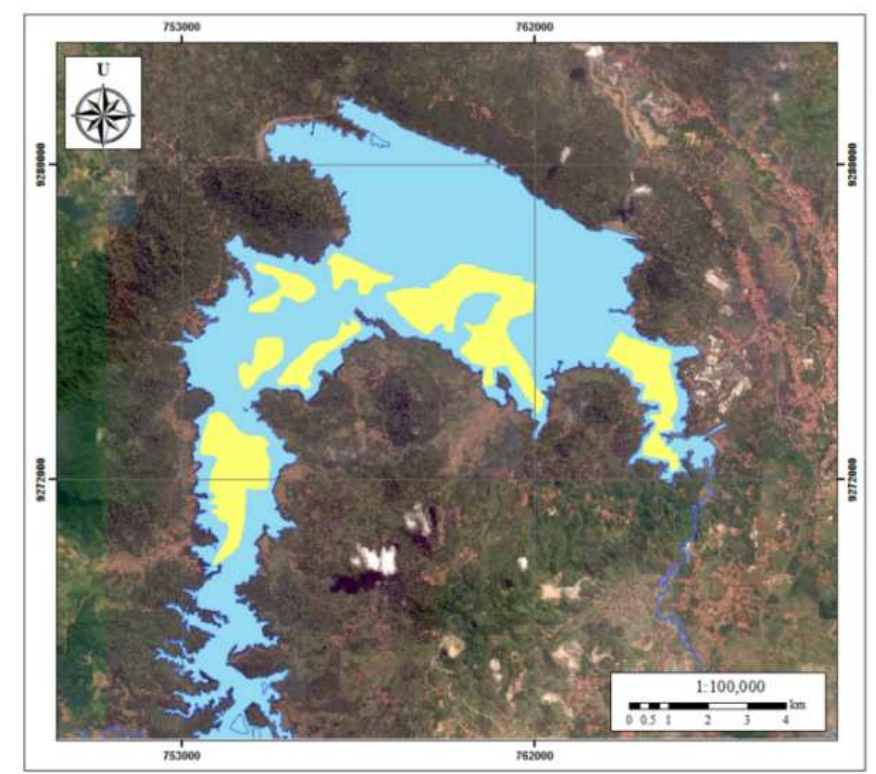

Fig. 1. Distribution of KJA at Jatiluhur Reservoir (Data analysis, 2016).

\subsection{Impact of KJA on Water Quality}

Nastiti said that the rapid development of the KJA unit has been positively impacting the increase of fish production and the income of fish farmers [8]. In his research, Nastiti measured KJA support capacity in Jatiluhur reservoir with dissolved oxygen parameters (dissolved oxygen/DO). Results show the highest DO in the dry season (July) and lowest DO during the rainy season (December) [8]. Research conducted in the year 2007 showed the levels of chemcical oxygen demand (COD) exceeds the threshold of the quality of drinking water, namely in the reservoir inlet, in the KJA area and in the domestic waste sewer area [6].

Research conducted in 2016 (Figure 2. A) showed total phosphorus distribution in Jatiluhur Reservoir. The red color indicates the total high phosphorus content, while the blue signifies total low phosphorus content. The eastern part of the reservoir has a red color indicating phosphorus in the high part. Figure 2. B shows total nitrogen distribution in the Jatiluhur Reservoir. The red color indicates a high total nitrogen content, while the blue indicates a low total nitrogen content. The southeastern part of the reservoir has a red color indicating the nitrogen content in the section is high. High nitrogen content can also be 
characterized by the presence of water hyacinth plants that grow on the edges and middle of the lake.

Research conducted in the year 2016 showed high DO value of $4.26-8.16 \mathrm{ppm}$ [9]. The water quality in Jatiluhur Reservoir is entered into a heavily polluted category (D). The increasing number of KJA in Jatiluhur Reservoir also leads to high nitrogen (N) and phosphorus (P) levels. The higher the number of KJA, the accumulation of organic materials in the reservoir water will also be higher [9]. The existence of KJA in Jatiluhur Reservoir is a serious threat, because when the waste of fish feed wasted reach $30 \%$, then the sedimentation due to feed waste reaches 82,800 tons per year [9].

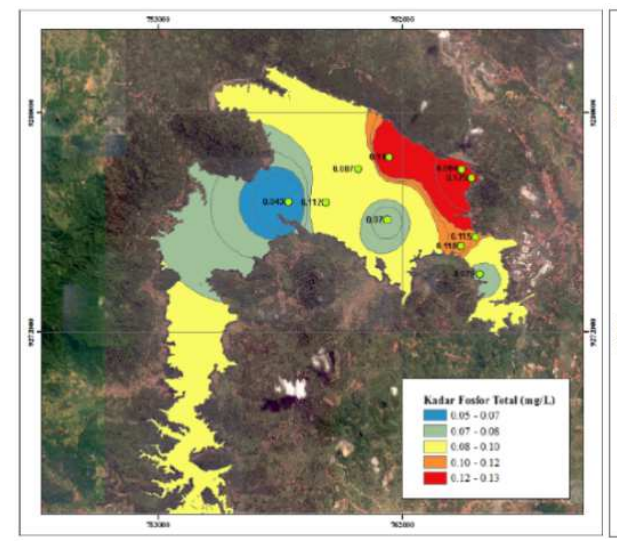

(a)

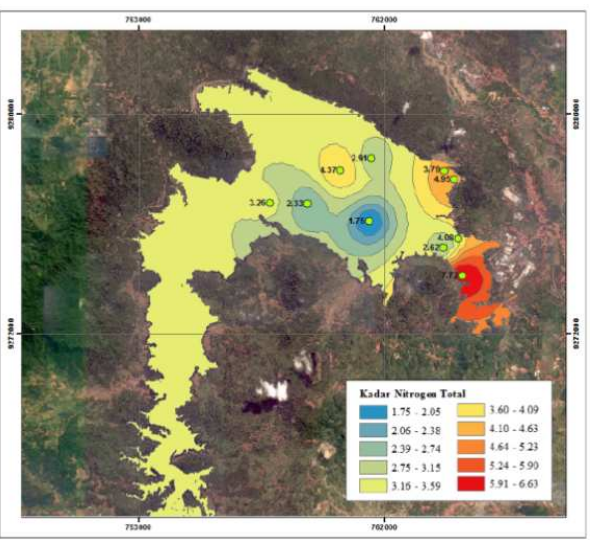

(b)

Fig. 2. Total Phosporus Distribution (a) and Total Nitrogen Distribution (b) (Data analysis, 2016)

\subsection{Impact of KJA one Economics}

Economically, KJA development priorities are addressed to the communities around the reservoir. The existence of KJA activity indirectly open the job and the opportunity to strive in the field of fisheries for the community around the reservoir [10]. According to the data in the year 2015, there are 1,290 farmers and 617 fishermen in Jatiluhur sub-district [11]. In the period 2005-2012 the number of RTP cultivates increased from 1,227 RTP to 2,135 RTP [11]. Fish production increased from 28,424 tons/year to 82,571 tons/year or equivalent to $\mathrm{Rp}$ $1.651,42$ billion [11]. The development of this sector has contributed significantly to the increase of the production of common aquatic aquaculture fisheries.

On the other hand, there is a decline in the quality of aquatic environment causing uncertainty the success of aquaculture business, where this activity can only give business advantage only if it is attempted in the size of certain business units (minimum 20 plots/RTP). This condition has a social impact on the shift in the rights of the holder, which is owned by the affected community, but currently some of the KJA cultivation is controlled by large financiers from outside the region [11].

\subsection{Other KJA Impacts}

The other impact of KJA is the invasion of foreign species that can change the structure of the original fish that caused food competition or predation. The form of the invasion of foreign 
species is an introduction of fish and the unintentional distribution of the type of fish from the KJA and fertilated KJA fish seeds because it does not match the seed expected [11].

The habitat change from flowing to Inundrum is also one of the factors of changing fish species in Jatiluhur reservoir. Only fish are able to adapt to the condition that the able persists. The loss of spawning habitat is one cause of decline or loss of native fish populations. Of the 24 types of native fish only live seven types of fish still caught in Jatiluhur Reservoir [11].

The impact of KJA on water quality degradation is also a factor that is bad for hydroelectric power (hydropower) equipment. This will result in damage or corrosion to the turbine that will reduce the life of the turbine. Fast corrosion machines and turbines, resulting in improved maintenance time and costs that can reduce operational hours [9].

\subsection{Zero KJA}

The number of KJA increases from year to year. Data showed in early 2000, KJA cultivation amounted to 2100 plots. This number increased rapidly to 25,951 plots in 2015 . The highest increase was in the transition from 2005 and 2006. At that time, the number of KJA 5,141 plots (2005) and increased more than twice as much as 13,814 plots (2016).

Table 1. Data on KJA population in Jatiluhur Reservoir 2000-2015

\begin{tabular}{|c|c|c|c|c|c|c|}
\hline \multirow{2}{*}{ No } & \multirow{2}{*}{ Year } & \multirow{2}{*}{$\begin{array}{c}\text { Plot } \\
\text { Population }\end{array}$} & \multirow{2}{*}{$\begin{array}{l}\text { Put in } \\
\text { Order }\end{array}$} & \multicolumn{2}{|c|}{ Inside The Zone } & \multirow[t]{2}{*}{$\begin{array}{c}\text { Outside The } \\
\text { Zone }\end{array}$} \\
\hline & & & & $\begin{array}{l}\text { There is } \\
\text { Contract }\end{array}$ & $\begin{array}{c}\text { There is No } \\
\text { Contract }\end{array}$ & \\
\hline 1 & 2000 & 2.100 & - & 2.100 & - & - \\
\hline 2 & 2001 & 2.130 & - & 11.730 & 400 & - \\
\hline 3 & 2002 & 2.159 & - & 1.840 & 319 & - \\
\hline 4 & 2003 & 3.216 & - & 2.853 & 363 & - \\
\hline 5 & 2004 & 3.513 & - & 3.208 & 305 & - \\
\hline 6 & 2005 & 5.141 & - & 4.003 & 1.138 & - \\
\hline 7 & 2006 & 13.814 & - & 6.314 & 7.500 & - \\
\hline 8 & 2007 & 14.000 & - & 5.000 & 9.000 & - \\
\hline 9 & 2008 & 16.200 & - & 5.200 & 11.000 & - \\
\hline 10 & 2009 & 19.279 & 134 & 16.545 & 1.641 & 1.093 \\
\hline 11 & 2010 & 19.630 & 424 & 12.592 & 3.953 & 3.085 \\
\hline 12 & 2011 & 21.579 & 827 & 14.488 & 3.091 & 4.000 \\
\hline 13 & 2012 & 20.752 & 272 & 13.665 & 3.087 & 4.000 \\
\hline 14 & 2013 & 23.476 & 98 & 7.822 & 16.215 & - \\
\hline 15 & 2014 & 25.951 & - & 9.703 & 14.043 & - \\
\hline 16 & 2015 & 25.951 & 1.536 & 1.556 & 22.859 & - \\
\hline
\end{tabular}

In 2000 although the number of KJA has not been as much as today, but Sutardjo research has anticipated the need for control of the number of KJA [10]. Sutardjo also said the need for socialization of the way of feeding in accordance with provisions, namely as much as $3 \%$ of the weight of cultivated fish. It aims to reduce the amount of residual feed that enters the water, so as to prevent the occurrence of water pollution [10]. According to the results of the research of Ismail, the potential impact of the KJA was to produce pollutants that caused the Jatiluhur reservoir to be polluted [7].

In 2018, the government issued a zero KJA policy. Looking at the recent 19-year study mentioned above, the authors agree with the issuance of the zero KJA policy. However, 
Governments should not close their eyes because KJA also impacts the economic sector. KJA in Jatiluhur Reservoir is one of the fish suppliers in West Java. The zero KJA policy the amount of fish production will decline.

The solution to maintaining employment for the community, the production of fish maintained and not damaging the environment is to use the technology of culture based fisheries $(\mathrm{CBF}) . \mathrm{CBF}$ is a form of restoration of fish resources. Previously, $\mathrm{CBF}$ was underutilized in increasing fishery production, over time, a number of developing countries acknowledged $\mathrm{CBF}$ as a key strategy in the improvement of nutritional and household economy fisheries to strive to facilitate the development of through the distribution programmes with the technology [12].

$\mathrm{CBF}$ is one form of fish distribution that is applied in the waters with the production of fish that is experiencing a decline or in the waters with the production of fish that is decreasing or on the water with poor fish resources (Types and quantities of fish are not much or low diversity) but have moderate to high fertility. The dosage of the fish is managed and owned both individually and collectively [13].

$\mathrm{CBF}$ is based on the distribution of fish seeds from the cultivation (seeding) that is carried out routinely. The fish that is stocked grows by utilizing natural food and the fish is not expected to breed in anticipation of its invasive character (adaptability and suppress the existence of other fish populations) [14].

\section{Conclusion}

Reviewing from the study report of 19 years backwards about the quality of the reservoir water due to KJA, it is proven that Jatiluhur Reservoir has been polluted. Zero KJA can be implemented in Jatiluhur Reservoir. The KJA Zero policy must be supported by other policies that pay attention to the amount of fish production and livelihoods of KJA farmers. Solutions to maintain the amount of fish production using culture based fisheries (CBF) technology.

\section{References}

[1] Presiden Republik Indonesia, Peraturan Presiden No. 15 Tahun 2018 Tentang Percepatan Pengendalian Pencemaran dan Kerusakan Daerah Aliran Sungai Citarum. 2018.

[2] M. Sholeh, P. Pranoto, S. Budiastuti, and S. Sutarno, "Analysis of Citarum River pollution indicator using chemical, physical, and bacteriological methods," in AIP Conference Proceedings, 2018, vol. 2049, no. 1, p. 20068.

[3] R. N. A. Aziz, "Model of Citarum Riverbasin Management Policy (DAS) in the Framework of Citarum Flood Control in Bandung Regency: a System Dynamics Approach," Univ. Indones. 2014.

[4] J. Loebis and P. Syariman, "Reservoir operation conflict in Citarum river basin management," IAHS Publ., p. 455, 1993.

[5] I. A. I. Dharmapatni and T. Firman, "Problems and challenges of mega-urban regions in Indonesia: the case of Jabotabek and the Bandung metropolitan area," The mega-urban regions of Southeast Asia. Vancouver: University of British Columbia Press, pp. 296-314, 1995.

[6] R. Maria, H. Lestiana, S. Sukristiyanti, N. Karningsih, and S. Sutarman, "Observasi Kualitas Air pada Waduk Jatiluhur," Pros. GEOTEKNOLOGI LIPI, 2007.

[7] L. Subehi, S. N. Ismail, I. Ridwansyah, M. A. Hamid, and M. Mansor, "Analysis of the 
influence of reservoirs utilization to water quality profiles in Indonesia (Saguling-Jatiluhur) and Malaysia (Temengor-Chenderoh) with special references to cascade reservoirs," in IOP Conference Series: Earth and Environmental Science, 2018, vol. 118, no. 1, p. 12025.

[8] A. S. Nastiti, S. Nuroniah, S. E. Purnamaningtyas, and E. S. Kartamihardja, "Daya Dukung Perairan Waduk Jatiluhur Untuk Budi Daya Ikan dalam Kerambajaring Apung," J. Penelit. Perikan. Indones., vol. 7, no. 2, pp. 14-21, 2017.

[9] H. Hamzah, M. S. Maarif, M. Marimin, and E. Riani, "The water quality status of Jatiluhur reservoir and threats to vital business process," J. Sumber Daya Air, vol. 12, no. 1, pp. 47-60, 2016.

[10] Sutardjo, "Pengaruh Budidaya Ikan pada Kualitas Air Waduk (Studi Kasus pada Budidaya Ikan dalam keramba Jaring Apung di Ciganea, Waduk Jatiluhur, Purwakarta, Jawa Barat)," Univ. Indones., 2000.

[11] A. L. S. Astuti, L. P.; Nurfiarini, A.; Sugianti, Y.; Warsa, A.; Rahman, A.; Hendrawan, Tata Kelola Perikanan Berkelanjutan di Waduk Jatiluhur, First. Yogyakarta: Deepublish, 2016.

[12] S. Silva, S. De; Ingram, B.; Wilkinson, Perspectives on culture-based fi sheries developments in Asia Perspectives on culture-based fi sheries developments in Asia, 3rd ed. Bangkok: NACA Monograph, 2015.

[13] FAO, Report of the APFIC/FAO Regional Consultation: Improving the contribution of culturebased fisheries and fishery enhancements in inland waters to Blue Growth. Negombo. Sri Lanka: RAP Publication, 2015.

[14] A. A. Aisyah, S. Triharyuni, E. Prianto, R. M. Purwoko, and H. Husnah, "Culture Based Fisheries (CBF) Sebagai Upaya Meningkatkan Produksi Ikan di Waduk," J. Kebijak. Perikan. Indones., vol. 11, no. 1, pp. 53-63, 2019. 